Acta Horticulturae et Regiotecturae 2

Nitra, Slovaca Universitas Agriculturae Nitriae, 2016, pp. 37-40

\title{
DURABILITY OF 28 GROUND-COVERING WOODY SPECIES AND CULTIVARS IN ROAD-SIDE PLANTING IN WARSAW, POLAND
}

\author{
Tatiana SWOCZYNA*, Piotr LATOCHA \\ Warsaw University of Life Sciences - SGGW, Warszawa, Poland
}

\begin{abstract}
Shrub species selection for road-side planting should consider their ability to cope with stress factors imposed by road trafic. In our examination we evaluated durability of 28 ground-covering woody species and cultivars in road-side environment in Warsaw. A dendrological inventory of planting beds located along Niepodległości Avenue was carried out 11 years after planting. The survival rate of each planted group of shrubs (a patch) was determined. Electrical conductivity of soil in planting beds was measured in order to determine soil salinity. Planting beds were divided into 3 groups: (1) wide beds at street corners, (2) narrow beds between pavements and interior roads, (3) road-side beds between interior roads and main roads. The results showed that the greatest number of shrubs was lost in the road-side planting beds, but in the wide beds and the narrow beds there were also some plant losses. The most resistant species to road-side environment were Spiraea $\times$ cinerea 'Grefsheim', certain cultivars of Spiraea japonica, Rosa rugosa and Ribes alpinum 'Schmidt'.
\end{abstract}

Keywords: ground cover shrubs, salt stress, urban environment

The problem of high mortality of urban trees has been widely discussed (Pauleit et al., 2002; Sæbø et al., 2003; Borowski and Pstrągowska, 2010). Harsh environmental conditions, quite different from those from natural stands, i.e. air and soil drought, decreased water deposition in soils, soil contamination and compaction, are considered to be the most important factors responsible for tree damage in cities (Sieghart et al., 2005; Sjöman and Nielsen, 2010; Swoczyna et al., 2015). Accumulation of de-icing salts in road-side soils is the additional stress factor affecting road-side trees in Central and Nothern Europe (Cekstere et al., 2008). The similar problem concerns shrubs, however, mortality of shrubs is not so much emphasised. Shrubs play a key role in urban environments. Planting of ornamental shrubs shifts the aesthetic value of city boulevards, streets and squares. When planted along streets, shrubs accumulate road contaminations due to their short height (Dzierżanowski et al., 2011). Simultaneously, they are affected both by road-side contamination and harmful abiotic factors. Therefore, shrub species and cultivars which are planted along streets should reveal tolerance to road-side conditions, i.e. to a complex of abiotic factors connected directly with close vicinity of roads, especially de-icing salt accumulation in soil.

The objective of our study was to evaluate 28 groundcovering woody species and cultivars durability in road-side environment.

\section{Material and methods}

The research was performed along Aleja Niepodległości, a downtown avenue in Warsaw, Poland $\left(52^{\circ} 12^{\prime} 20^{\prime \prime}\right.$
$\left.\mathrm{N}, 21^{\circ} 00^{\prime} 33^{\prime \prime} \mathrm{E}\right)$, oriented in North-South direction, supporting heavy traffic. Three types of planting beds were established:

1. wide beds of $6.5-10 \mathrm{~m}$ width at street corners,

2. narrow beds of $1.6-2.8 \mathrm{~m}$ width between pavement and interior roads,

3. road-side beds of $1.5-2.5 \mathrm{~m}$ width between interior roads and main roads (Figure 1 ).

Ground cover shrubs were planted in 2004 in patches consisting of 30 to 120 specimens due to a design made by Agnieszka Matyszczyk, Zarząd Oczyszczania Miasta (ZOM) Metropolitan Authority of Parks, Greenery and Cleaning, Warsaw. In wide planting beds, shrubs were planted in irregular patches, in narrow and road-side beds, shrub patches formed rows arranged one by one along each planting bed. Due to dendrological inventory performed in 2005 (Królikowska, 2006), the following species and cultivars were used: Berberis thunbergii DC. 'Atropurpurea', B. thunbergii 'Atropurpurea Nana', B. thunbergii 'Green Carpet', Cotoneaster dammeri C.K.Schneid. 'Eichholz', C. dammeri 'Major', Cotoneaster horizontalis, Cotoneaster $\times$ suecicus G. Klotz 'Coral Beauty', Euonymus fortunei (Turcz.) Hand.-Mazz. 'Coloratus', Forsythia 'Maree d'Or', Hedera helix L., Mahonia aquifolium (Push) Nutt., Physocarpus opulifolius (L.)Maxim. 'Diabolo', Ph. opulifolius 'Luteus', Potentilla fruticosa L. 'Goldfinger', Ribes alpinum L. 'Schmidt', Rosa rugosa Thunb., Rosa 'The Fairy', Sorbaria sorbifolia (L.)A. Br., Spiraea $\times$ cinerea Zabel 'Grefsheim', Spiraea japonica L. 'Anthony Waterer', S. japonica 'Froebelli', S. japonica 'Golden Princess', S. japonica 'Goldflame', S. japonica 'Goldmound', S. japonica 'Little Princess', Stephanandra incisa (Thunb.) Siebold \& Zucc. ex Zabel 'Crispa', Symphoricarpos $\times$ chenaulti 


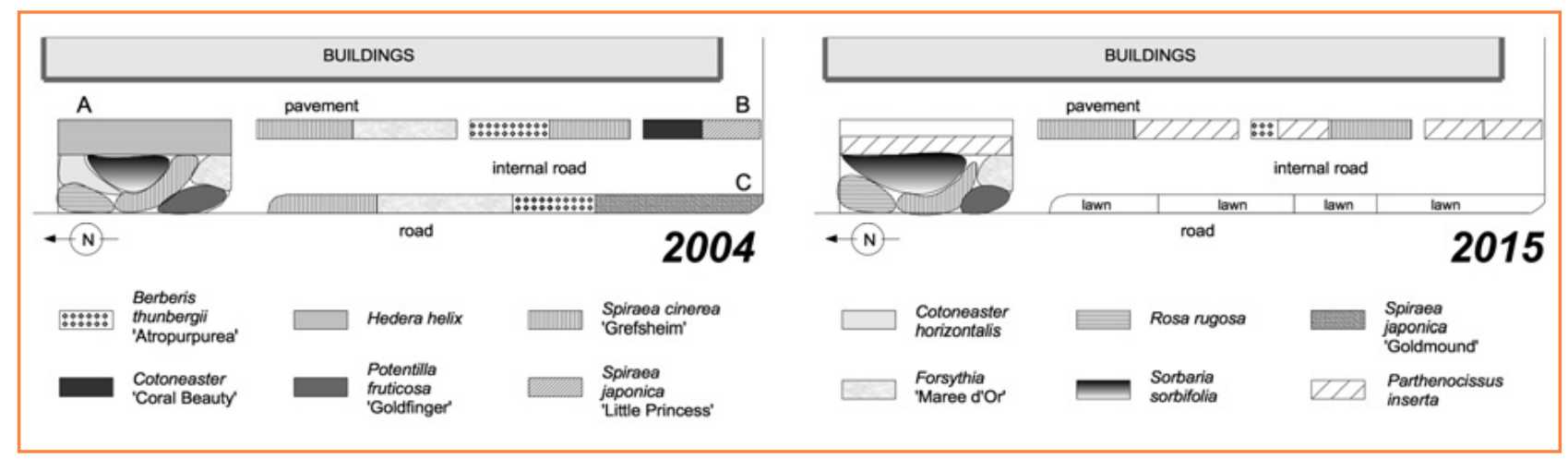

Figure 1 The example of ground cover shrubs' arrangement in Niepodległości Avenue in 2004 and 2015 Source: Drawn by T. Swoczyna

A - wide planting beds, B - narrow planting beds, C - road-side planting beds

Table 1 Scale for evaluation of ground cover shrubs' survival

\begin{tabular}{|l||c|}
\hline Class & Degree of survival \\
\hline $\mathbf{0}$ & no specimen survived \\
\hline $\mathbf{1}$ & only single specimens survived \\
\hline $\mathbf{2}$ & less than $75 \%$ of total specimens survived \\
\hline $\mathbf{3}$ & more than $75 \%$ of total specimens survived \\
\hline
\end{tabular}

Rehder 'Hancock', Weigela florida (Bunge)A.DC. 'Nana Variegata'. Shrubs were maintained due to procedures accepted by ZOM (watering, fertilising, weeding).

In August 2015, the inventory and evaluation of plant survival was proceeded. Every patch was given a number and for each one the rate of plant survival was evaluated, according to a scale given in Table 1.

In the beginning of September 2015 , soil salinity in planting beds was measured. Soil samples were collected from wide beds and road-side beds, $1 \mathrm{~m}$ from the road edge, and from the middle line of narrow beds, each at $0-0.2 \mathrm{~m}$ depth. Three replications from each type of planting beds and an additional sample from lawn area of a neighbouring park were taken for laboratory analyses. The electrical conductivity of soil was measured using a CX-551 multifunction meter (ELMETRON Sp. j., Zabrze, Poland).

For statistical analysis, KruskallWallis test was performed using STATISTICA 10.0 software (StatSoft, Inc., Tulsa, OK, USA).

\section{Results and discussion}

The species arrangement in all planting beds changed during 11 years. In many patches, plants were totally lost, especially in road-side planting beds (Figure 1 and 2). The survival of shrubs in road-side planting beds was significantly lower than in wide and narrow beds $(p=0.000$ and $p=0.042$, respectively).

Soil salinity expressed as electrical conductivity (EC) was higher in the Survival rate according to table 1 Source: Authors' original work close vicinity of the road edge (Table 2). Although the measurements were done in the end of the growing season, the salt deposition in road-side soils still remained very high. This may explain the poor survival of road-side shrubs. According to Marosz and Nowak (2008), EC values exceeding $2 \mathrm{mS} \mathrm{cm}^{-1}$ seriously affect young trees. In woody plants, de-icing salts are accumulated in tissues and prove to cause severe injuries after long-term exposition to salt stress (Pracz, 1990; Cekstere et al., 2008). Harmful impact of soil salinity consists both in accumulations of toxic ions in plant tissues and in osmotic limitations to water absorption by roots. Additionally, restricted soil volume supported to urban trees is often responsible for water scarcity which affects urban trees (Sieghart et al., 2005). In our research the restricted soil volume in the road-side planting beds might have precluded

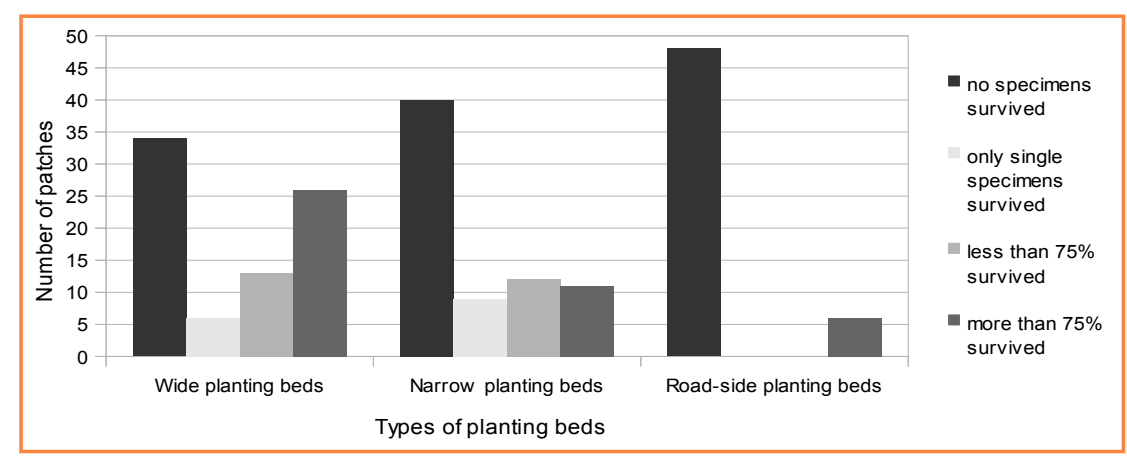

Figure 2 Total ground cover shrubs' survival in three types of planting beds.

Table 2 Soil salinity expressed as electrical conductivity (EC) in planting beds and park lawn (control). Means and SE are shown

\begin{tabular}{|l||c|c|c|c|}
\hline Site & Control & Narrow beds & Road-side beds & Wide beds \\
\hline EC $\left(\mathbf{m S ~ c m}^{-1}\right)$ & $0.724( \pm 0.171)$ & $1.122( \pm 0.070)$ & $2.268( \pm 0.272)$ & $2.379( \pm 0.364)$ \\
\hline
\end{tabular}

Source: Authors' original work 


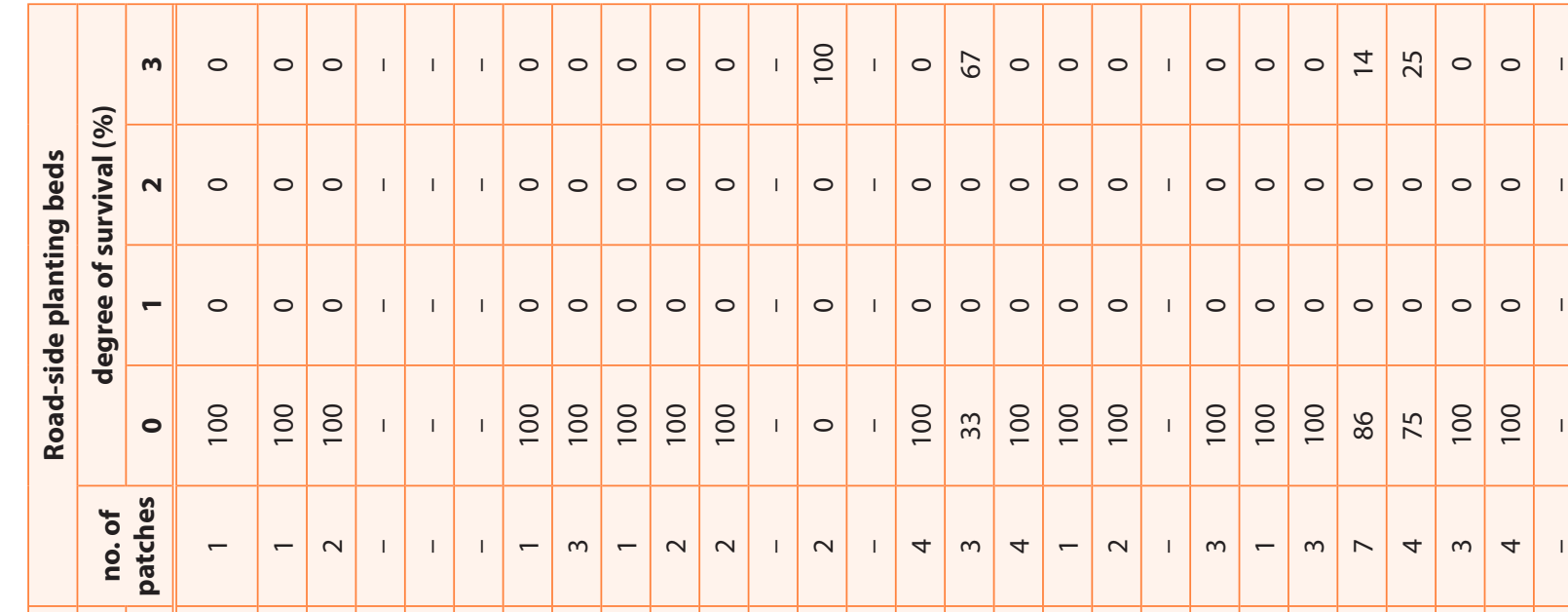

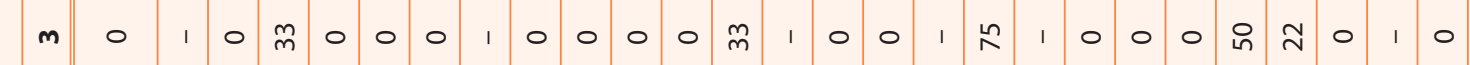

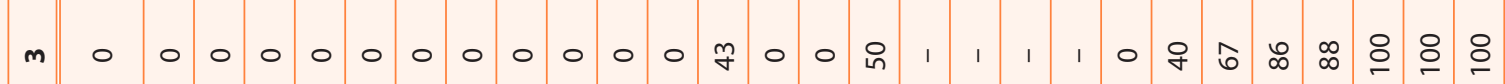

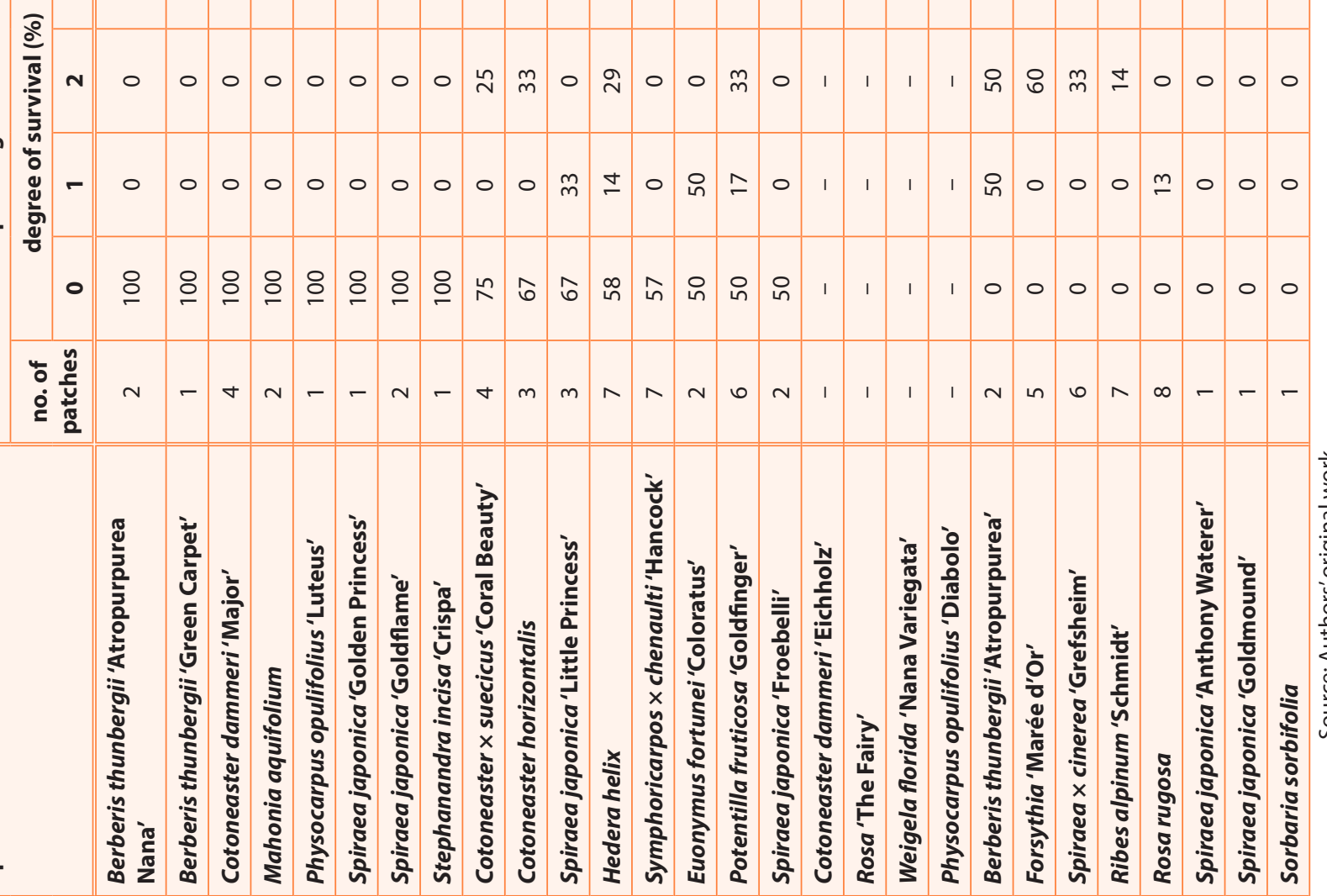


water storage in soil and, consequently, could have shifted detrimental effect of soil salinity. Although the soil salinity in the wide planting beds was similar compared to the road-side beds, the shrub survival rates in wide beds were higher. Presumably, the enlarged area of planting beds enabled better water accumulation in soil and this could have moderated the effect of the high soil salinity.

The survival rates of particular species and cultivars show some differences between the taxa. The number of experimental plots, i.e. patches, does not allow conducting successful statistical analysis. However, the insight into species-specific survival rates gives some suggestions on individual species durability in road-side environment. The results showed that the most resistant species were Spiraea $x$ cinerea 'Grefsheim', certain cultivars of Spiraea japonica, Rosa rugosa and Ribes alpinum 'Schmidt' (Table 3). Salt tolerance of Spiraea $\times$ cinerea 'Grefsheim' was confirmed by Marosz (2004). He also found Potentilla fruticosa and Cotoneaster horizontalis to be salt resistant, however, in our examination no specimens of these species survived in road-side planting beds. Taking into account drought stress, Percival \& Sheriffs (2002) classified Spiraea japonica 'Shirobana' as a droughtsensitive taxon. On the contrary, they found Hedera helix and Mahonia aquifolium to be tolerant. The discrepancy between Marosz's, Percival \& Sheriffs's and our results indicates that in road-side environments a complex of abiotic stress factors creates a specific pattern of plants' reactions. Laboratory experiments may indicate the resistance to some particular stress factors applied in a given time. Observations in situ allow evaluating plant ability to cope with a complex of stress factors affecting plants during their whole life span. This ability includes also recovery potential which is connected with the type of growth, for example, the ability to sucker. In our examination Sorbaria sorbifolia was the only species with markedly enlarged area (Figure 1), however, there was the only patch filled with Sorbaria sorbifolia. Thus, we cannot conclude whether this species is able to cope with road-side stress.

The opinions on the tolerance of shrub species to urban and road-side conditions are mostly based on individual observations. Therefore, scarce publications give only some general information on taxa which are appropriate for urban planting (Borowski \& Latocha, 2006). This examination confirms some of Borowski \& Latocha's opinions on Cotoneaster ssp. susceptability. Contrary to that, Symphoricarpos $\times$ chenaulti 'Hancock' appeared to be tolerant enough in road-side conditions. Surprisingly, Berberis thunbergii which is considered to be tolerant enough to drought revealed to be susceptible in road-side environment.

\section{Conclusions}

Road-side environments harmfully affect ground-covering shrubs. The list of species which can cope with environmental stress caused by heavy traffic is limited and includes Spiraea $\times$ cinerea 'Grefsheim', some cultivars of Spiraea japonica, Rosa rugosa and Ribes alpinum 'Schmidt'. The highest mortality of shrubs occurs in planting beds situated in close proximity to roads. In order to increase the durability of ground cover shrubs the designed and established planting beds along streets should have greater area (exceeding $3 \mathrm{~m}$ width).

\section{References}

BOROWSKI, J. - LATOCHA, P. 2006. Dobór drzew i krzewów do warunków przyulicznych Warszawy i miast centralnej Polski [Trees and shrubs suitable for street conditions in Warsaw and other cities in central Poland]. In Rocznik Dendrologiczny, 2006, no. 54, pp. 83-94. BOROWSKI, J. - PSTRĄGOWSKA, M. 2010. Effect of street conditions, including saline aerosol, on growth of the Small-leaved limes. In Rocznik Polskiego Towarzystwa Dendrologicznego, 2010, no. 58, pp. 15-24.

CEKSTERE, G. - NIKODEMUS, O. - OSVALDE, A. 2008. Toxic impact of the de-icing material to street greenery in Riga, Latvia. In Urban Forestry \& Urban Greening, vol. 7, 2008, no. 3, pp. 207-217.

DMUCHOWSKI, W. - BADUREK, M. 2004. Chloride and sodium in the leaves of urban trees in Warsaw in connection to their health condition. In Chemia i Inżynieria Ekologiczna, vol. 11, 2004, no. 4-5, pp. 297-303.

DZIERŻANOWSKI, K. - POPEK, R. - GAWROŃSKA, H. - SAB Ø, A. GAWROŃSKI, S.W. 2011. Deposition of particulate matter of different size fractions on leaf surfaces and in waxes of urban forest species. In International Journal of Phytoremediation, 2011, no. 13, pp. 1037-1046. KRÓLIKOWSKA, K. 2006. Assessment of usefulness of choosen ground cover shrubs for planting in close vicinity of large thoroughfares. (in Polish) Master's thesis, Warsaw : WULS, 2006. 144 pp.

MAROSZ, A. 2004. Effect of soil salinity on nutrient uptake, growth, and decorative value of four ground cover shrubs. In Journal of Plant Nutrition, vol. 27, 2004, no. 6, pp. 977-989.

MAROSZ, A. - NOWAK, J.S. 2008. Effect of salinity stress on growth and microelements uptake of four tree species. In Dendrobiology, 2008, no. 59, pp. 23-29.

PAULEIT, S. - JONES, N. - GARCIA-MARTIN, G. - GARCIAVALDECANTOS, J.L. - RIVIÈRE, L.M. - VIDAL-BEAUDET, L. - BODSON, M. - RANDRUP, T.B. 2002. Tree establishment practice in towns and cities - Results from a European survey. In Urban Forestry \& Urban Greening, 2002, no. 1, pp. 83-96.

PERCIVAL, G.C. - SHERIFFS, C.N. 2002. Identification of droughttolerant woody perennials using chlorophyll fluorescence. In Journal of Arboriculture, vol. 28, 2002, no. 5, pp. 215-223.

PRACZ, J. 1990. Reakcja drzew i krzewów na zasolenie gleb chlorkiem sodu [Trees and shrubs reaction on sodium chloride in the soil]. (in Polish) In CPBP 04.10. Problemy ochrony i kształtowania środowiska przyrodniczego na obszarach zurbanizowanych. Warszawa : Wydawnictwo SGGW-AR., pp. 257-268.

SAB $\varnothing$, A. - BENEDIKZ, T. - RANDRUP, T.B., 2003. Selection of trees for urban forestry in the Nordic countries. In Urban Forestry \& Urban Greening, 2003, no. 2, pp. 101-114.

SÆBØ, A. - BORZAN, Ž. - DUCATILLION, C. - HATZISTATHIS, A. LAGERSTRÖM, T. - SUPUKA, J. - GARCÍA-VALDECANTOS, J.L. - REGO, F. - VAN SLYCKEN, J. 2003. The selection of plant materials for street trees, park trees and urban woodland. In Konijnendiijk, C.C. - Nilsson, K. - Randrup, T.B. - Schipperijn, J. (Eds.) Urban Forests and Trees, Berlin : Springer, 2003. pp. 257-280.

SIEGHARDT, M. - MURSCH-RADLGRUBER, E. - PAOLETTI, E. COUENBERG, E. - DIMITRAKOPOULUS, A. - REGO, F. - HATZISTATHIS, A. - RANDRUP, T.B. 2005. The abiotic urban environment: impact of urban growing conditions on urban vegetation. In Konijnendijk, C.C. Nilsson, K. - Randrup, T.B. - Schipperijn, J. (Eds.). Urban Forests and Trees, Springer, Berlin, 2005. pp. 281-323.

SJÖMAN, H. - NIELSEN, A.B. 2010. Selecting trees for urban paved sites in Scandinavia - A review of information on stress tolerance and its relation to the requirements of tree planners. In Urban Forestry \& Urban Greening, 2010, no. 9, pp. 281-293.

SUKOPP, H. - WURZEL, A. 2003. The effects of climate change on the vegetation of central European cities. In Urban Habitats, vol. 1, 2003, no. 1, pp. 66-86.

SWOCZYNA, T. - KALAJI, H.M. - PIETKIEWICZ, S. - BOROWSKI, J. 2015. Ability of various tree species to acclimation in urban environments probed with the JIP-test. In Urban Forestry \& Urban Greening, vol. 14, 2015, no. 3, pp. 544-553. 